ワイトネッド型開口器を挿入し，舌圧子で分界溝を圧

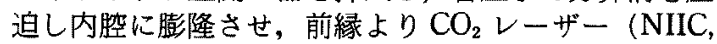
model, 60)にて舌扁桃組織を蒸散させた。喉頭蓋谷付 近の直接明視下に蒸散し得ない部分については，反射 鏡を用いて蒸発，気化させた。術中の出血は軽度であ り，手術時間は，摘除すべき舌扁桃の組織量によるが
平均30分程度で終了した，街後の疼痛は 3 日から4 日 程度で消失し，同時に術前の咽喉頭異常感も消失する 例が多かった，また術創の白苔は 1 週間から10日で消 失し, 術後出血もなかった, 以上, 舌扁桃肥大に対し て, $\mathrm{CO}_{2}$ レーザー手術を適用し, 従来の方法にかるる 有効の手術法であると思われた。

\title{
10．鼻内手術前後の嗅裂所見と嗅覚機能の関係
}

\author{
李 延権・朴 仁勇・鄭 勝圭（鹿大・延世大）
}

目的 副鼻腔炎や鼻アレルギーなどによって起こる 呼吸性嗅覚障害患者の嗅裂の閉塞度と嗅賞機能の関係 に注目し，鼻内手術の前後で㭡裂の閉塞度を計測する とともに嗅覚検查を行い，両者の関係を検討した。 た，嗅裂の外科的な開大が嗅覚機能の改善に及ぼす効 果についても検討した結果，興味ある成績が得られた ので，報告した。

対象と方法 対象症例は昨年 1 年間に延世大学校永 東 Severance 病院耳鼻咽喉科で慢性副鼻腔炎及び鼻 中隔彎曲症の診断にて鼻内手術を行った104例である。 また鼻疾患を有しない成人47例をControl 群とした。 嗅裂の閉塞度は綿棒が通過する程度により, 過大開存, 適度開存, 接着, 疹着の 4 段階に分類した。ささらに膿 性鼻漏の有無および副鼻腔 X 線検查に招ける陰影の 有無によって術前に鼻腔内に炎症がある群とない群と に分けて, 比較娭討を行った. 嗅覚検査法として, T\& T Olfactometry と静脈性嗅賞倹査法を用いて平均検 知ならびに認知闘值と潜伏時間ならびに持続時間を求
めた。なお鼻内手術時には嗅裂の開大を行った。

結果 T \& T Olfactometer の成績をみると, 症例 群では Contmol 群に比べ平均検知闘值および平均認 知䦪値ともに有意に上昇した。また静脈性嗅覚検查で も症例群では Control 群に比べ潜伏時間の有意な延長 と持続時間の有意な短縮が認められた。嗅裂の閉塞度 と嗅賞検查成績を比較すると，閉塞が高度なほど嗅賞 機能も低下した。洼後の嗅覚検查成績をみると，術前 の嗅裂の閉塞が高度で，嗅覚検查成績が悪かった例ほ ど高い改善度を示した。術前鼻粘膜に炎症所見が認め られた症例では炎症が認められなかった例と比較する と, 術前の嗅覚機能は低下し，これは術後有意に改善 した．以上の成績により嗅裂の形態異常が嗅賞機能に 大きく関与していることおよび鼻の手術時に嗅裂の開 大を行うことで嗅覚機能が大いに改善することが示さ れた。従って，嗅覚機能の改善度が鼻科手術の成否を 示す 1 つ指標としても利用できると思われる。

\section{1. 鼻粘膜のペプタイド含有線維}

Peptidergic nerve fibers in nasal mucosa

\section{蘇 萬全（福岡大・台北医学院大）}

目的 鼻粘膜に分布する神経は adrenergic nerve (Adn) と cholinergic nerve (Chn) と言われてきたが, 近年, ペプタイドの発見と免疫学的手法の発達によっ $\tau$ peptide-containing fiber $の$ 存在が明らかになって きた. そこで, 今回は, モルモットの鼻粘膜で, Adn, Chnのほか, vasoactive intestinal polypeptide (VIP), calcitonin gene-related peptide (CGRP), substance P (SP), neurokinin A (NKA) の抗体を 用い, それぞれの神経の分布椂相ならびに相互関係を 検討した。

方法 神経ペプタイドに対しては, Zamboni 固定液 で頭部灌流し，鼻粘膜を剥離し，24時間同固定液中で 浸漬固定し，凍結切片にし，VIP， CGRP, SP および NKA の抗体を作用させ，PAP法に従って反応させ た. Adnには Falck-Hillarpカテコラミン蛍光法,
表 1 モルモット鼻粘膜の神経分布

\begin{tabular}{|c|c|c|c|}
\hline & 血 管 & 腺 & 上皮下層 \\
\hline Adn. & $+\#$ & \pm & \\
\hline Chn. & $+\#$ & + & \\
\hline VIP & + & + & \pm \\
\hline CGRP & + & + & + \\
\hline $\mathrm{SP}$ & + & + & + \\
\hline $\mathrm{NKA}$ & + & + & + \\
\hline
\end{tabular}

$\pm:$ 極めて疎，+：疎， +

Chnには Karnovsky-Roots の AChE 活性染色法を 
表 2 モルモット鼻粘膜における NKA および SP の濃度

\begin{tabular}{|c|c|c|c|c|}
\hline 鼻＼cjkstart粘＼cjkstart膜 & 動物数 & $\begin{array}{c}\text { 湿重量 }(\mathrm{mg}) \text { 当りの } \\
\text { NKA 量 }(\mathrm{pg})\end{array}$ & $\begin{array}{c}\text { 湿重量 }(\mathrm{mg}) \text { 当りの } \\
\text { SP 量 }(\mathrm{pg})\end{array}$ & $\mathrm{SP} / \mathrm{NKA}$ \\
\hline 鼻 中 隔 & 5 & $14.4 \pm 1.2$ & $10.5 \pm 0.2$ & 0.7 \\
\hline 鼻甲介その他 & 5 & $21.0 \pm 1.4$ & $19.5 \pm 1.2$ & 0.9 \\
\hline
\end{tabular}

平均値士標準誤差

用いた。 なお Radio-immunoassay では，上澄液を凍 結乾燥後, ${ }^{125}$ I-SP (New England Nuclear), ${ }^{125}$ INKA (Amershan) を使用して Mroz \& Leeman の方 法に従って RIA 測定した。

結果 Adn は血管系, 特に, 静脈系では血管壁に非 常に密な網目状の分布を示すが, 腺組織では腺体およ び導管のいずれにおいてもきわめてわずかしか認め得 ない.Chnは血管系抢よび腺組織ともに密な分布を示 す。一方, peptidergic nerve fiberでは, VIP 含有線 維は Adn, Chnよりかなり少なく，腺体扔よび導管で はかなり多いが血管壁および上皮下組織では少なくな
る. CGRP 含有線維は血管，腺执よび粘膜下層でかな り多く存在する. SP および NKA 含有線維は血管壁, 腺抢よび上皮下層にわずかに存在し，SP拈よび CGRP 線維は粘膜上皮内にも存在している.上記の結 果を総括すると表 1 の通りである。鼻中隔部扔よび鼻 甲介部の $1 \mathrm{mg}$ 当たりの NKA 掞よび $\mathrm{SP}$ 量を比較検 討すると，いずれも鼻甲介部が多い。さらに, NKA と $\mathrm{SP}$ 量 $(\mathrm{SP} / \mathrm{NKA})$ を比較すると, 鼻中隔部では $\mathrm{NKA}$ が SPよりかなり，鼻甲介部では NKA が SP よりわ ずかに多い。その結果は表 2 の通りである。

\section{DISTRIBUTION OF SP, CGRP, AND VIP IN THE GUINEA PIG NASAL MUCOSA SENSITIZED BY TOLUENE DIISOCYANATE (TDI)}

B. Kalubi（阪大・ザイール，キンシャサ大） 入船盛弘・荻野 敏・松永 亨（阪大）遠山政弥（同・第二解剖）

Toluene disocyanate (TDI) is known to induce clinical symptoms of respiratory hypersensitivity in the mammals including man. Present immunohistochemical study has demonstrated in the Guinea pig that TDI treatment resulted in increase in number and intensity of Substance P (SP) and Calcitonin Gene Related Peptide (CGRP)-like immunoreactive fibers in the nasal mucosa, while failed to cause changes in the distribution of Vasoactive Intestinal Peptide (VIP) immunoreactive fibers.

Introduction It has been demonstrated that stimulation of the sensory nerve fibers in the nasal mucosa of mammals including human causes inflammation ${ }^{3448) 10}$. It is likely that this effect is due to the release of neuroactive substances from the endings of sensory nerve fibers. In fact release of SP and CGRP in the nasal mucosa was confirmed pharmacologicaly in the animals whose nasal mucosa sensory fibers were stimulated. However, it is still unclear whether or not SP and CGRP are reflexly released or they are produced actively from the nerve endings in this animal. Accordingly, in the present study, we have attempted to elucidate the changes of SP, CGRP and VIP immunoreactive fibers in the nasal mucosa after treatment with TDI which is known to cause respiratory hypersen. sitivity.

Material and Methods Guinea pig weighing about $250-300 \mathrm{~g}$ were used in this study. Animals were divided into 2 groups : one treated by TDI and an other was a control group. The sensitization process was done by local and daily application of $10 \%$ TDI solution to the nasal mucosa for 5 days. After 3 weeks of observation, application of $10 \%$ TDI was repeated for an other 5 days period. One week after the final application, 5\% TDI sol. was applied locally for provocation test once a week for 7 weeks. Animals showing a positive reaction (sneezing, rhinorrhea) to the provocation test were selected and nasal mucosa samples were subjected to immunohistochemistry.

Results In the control animals, many SP and CGRP fibers were seen in the nasal mucosa. In the lamina propria, a number of immunoreactive fibers were associated with blood vessels and seromucous glands. Several fibers often left the lamina propria to enter the epithelium. VIP fibers showed a similar distribution pattern to those of SP and CGRP, but very few fibers entered the epithelium. TDI 